Institute of $\mathbf{F}_{\text {ood and }} \mathbf{A g r i c u l t u r a l}_{\mathbf{S}} \mathbf{S}_{\text {ciences }}$

\title{
Say Goodbye to Mildew and Save Energy Home Study Course - Part I: What is Mildew ${ }^{1}$
}

Virginia Peart ${ }^{2}$

Moisture problems, such as mildew and corrosion, cost residents of Florida and other southeastern coastal regions millions of dollars. You may have heard horror stories about mildew: mildew throughout a home on walls, fabrics, and furnishings; costly clean-up and repainting jobs that don't last because mildew comes back again and again; people who are allergic to mildew, but can't rid their homes of musty smells.

Running air conditioning continually to eliminate mildew problems, without controlling moisture, requires a lot of electric energy. As power production costs continue to rise, electrical utility bills rise. To save energy, to save money, to avoid the work of mildew clean-up and potential mildew allergy problems, people want to prevent mildew problems. If they already have mildew problems, they would like to stop them and keep mildew from spreading. Prevention of mildew in warm, humid climates requires an understanding of both mildew, what makes it grow and spread, and what can be done to control the situation.

\section{Part I}

There are many types of mildew, but what makes mildew grow is pretty much the same for every type. The conditions that promote or stop mildew growth are the same in all parts of the country or anywhere in Florida. Part I of this home study course can help you understand what mildew is and what makes it grow.

Mildew likes a warm, humid climate. We know, because in Florida it readily grows outside during humid periods. There is considerable confusion about when and why indoor mildew problems occur. The problem is that people are comfortable at a range of temperatures and humidity levels. Mildew also thrives at a wide range of temperature and humidity levels.

Unfortunately, there is some overlap between good temperature/humidity levels for mildew and humans. Notice the overlap area where both people are comfortable and mildew will grow.

1. This document is FCS 3211, one of a series of the Department of Family, Youth and Community Sciences, Florida Cooperative Extension Service, Institute of Food and Agricultural Sciences, University of Florida. Publication date: September 2002. First published in December 1990 by the Florida Energy Extension Service. Reviewed: September 2002 Please visit the EDIS Web site at http://edis.ifas.ufl.edu

2. Written by Virginia Peart, former Associate Professor, Housing, Department of Family, Youth and Community Sciences, Cooperative Extension Service, Institute of Food and Agricultural Sciences, University of Florida, Gainesville, 32611 and reviewed by Nayda I. Torres, Professor, Family and Consumer Economics, Department of Family, Youth and Community Sciences, Cooperative Extension Service, Institute of Food and Agricultural Sciences, University of Florida and Dale Dorman, Extension Housing and Environment Specialist - Emeritus, Cooperative Extension Service, University of Georgia.

The Institute of Food and Agricultural Sciences is an equal opportunity/affirmative action employer authorized to provide research, educational information and other services only to individuals and institutions that function without regard to race, color, sex, age, handicap, or national origin. For information on obtaining other extension publications, contact your county Cooperative Extension Service office. Florida Cooperative Extension Service / Institute of Food and Agricultural Sciences / University of Florida / Christine Taylor Waddill, Dean 
This is the MILDEW ALERT area. The lower limits for controlling mildew problems is about $70^{\circ} \mathrm{F}$ and 60 percent relative humidity. (See Figure 1.)

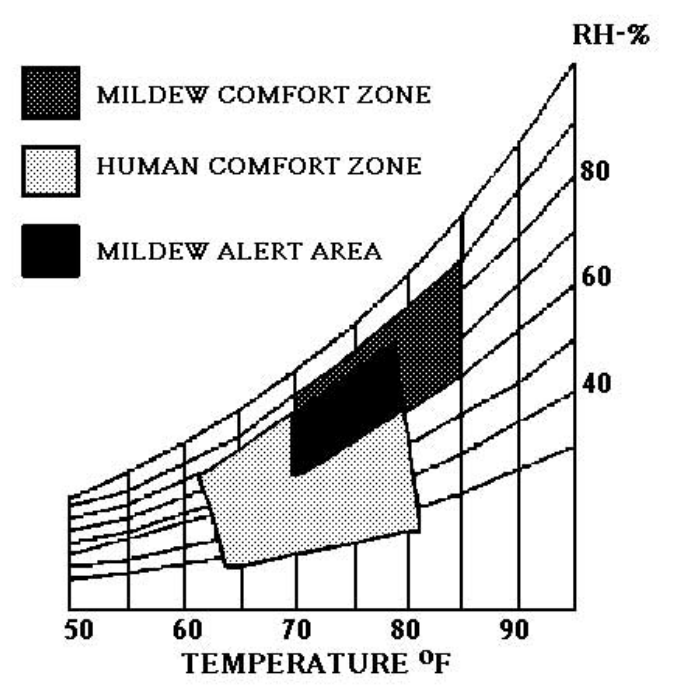

\section{What is Mildew?}

Mildew is a type of mold. Mold spores, the "seeds" from which mildew grows, are everywhere. In Florida, conditions are right for mildew to grow almost all of the time out-ofdoors. Mildew is common in shady areas and under dead leaves. There is no way we can keep mildew spores from entering our homes. Mildew spores are always with us.

\section{What Makes Mildew Grow?}

Mildew must have food to grow on, the right temperature, the right relative humidity and oxygen. Mildew grows readily on any organic material such as paper, leather, natural fibers, untreated wood, and many of the foods we eat. Mildew will grow on any material if there is the slightest amount of organic matter on it such as smears of food or even body oils in a shower stall. On porch furniture mildew usually shows up first where hands touch leaving a light layer of oil.

\section{Light is Not Needed}

What is not needed is light. Mildew can grow in the darkest closets. Ordinary light doesn't kill mildew, though ultra-violet light can kill it.

The ultra-violet light in sunshine can kill mildew. Before air conditioning, some people in Florida put their shoes and many other household items out in the sun each week and sunned them to keep mildew away.

\section{What Inhibits Growth?}

Mildew can also be stopped, at least temporarily, with very high or very low temperatures, low relative humidity and/or by using certain materials which act as fungicides. Forms of chlorine such as chlorine bleach and chlorinated phenols, copper naphthenate, or coaltar also inhibit mildew growth. Fungicides must be used with care as they can be unsafe or toxic to people and pets. And remember, too, that fungicides are not a permanent solution to mildew problems.

The most important factors for controlling mildew growth can be explained by this mildew equation: Spores + Humidity + Food + Heat $=$ Mildew

Mildew spores are everywhere and will come inside homes in warm, humid climates every time doors and windows are opened or air infiltrates a house through cracks around doors and windows. Of course, keeping your home clean is important when trying to prevent mildew, but, with normal family living, "mildew food" is impossible to completely eliminate. Smears from sticky fingers and even tiny spills provide mildew food. Of course, many materials used in the structure and furnishings in a home also provide nutrients for mildew. We can't live in a completely sterile 
environment. That leaves heat and humidity as controlling factors.

Temperatures must be below about $70^{\circ} \mathrm{F}$ to completely stop mildew growth. That's too cool for summer comfort. That means humidity control is very important.

Mildew requires moisture. The optimal growth range for mildew is 70 to $93 \%$ relative humidity. The relative humidity would have to be below $62 \%$ to completely stop all chances for growth, although below $70 \%$ inhibits most mold growth.

Temperature and relative humidity are closely related. Warm air can hold more moisture than cool air. For example, $90^{\circ} \mathrm{F}$ air at $50 \%$ relative humidity is warm enough for mildew to grow, but too dry. The relative humidity is too low. If this same air is cooled to $80^{\circ} \mathrm{F}$ without either increasing or decreasing the amount of water it holds, the relative humidity will be about $70 \%$, because $80^{\circ}$ air cannot hold as much moisture. Mildew can thrive at $80^{\circ} \mathrm{F}$ and $70 \%$ relative humidity. A lot of moisture must be removed from air in warm, humid climates like Florida to protect a home from mildew.

\section{Test Your Knowledge}

See the quiz to test your knowledge.

QUIZ

What is Mildew?

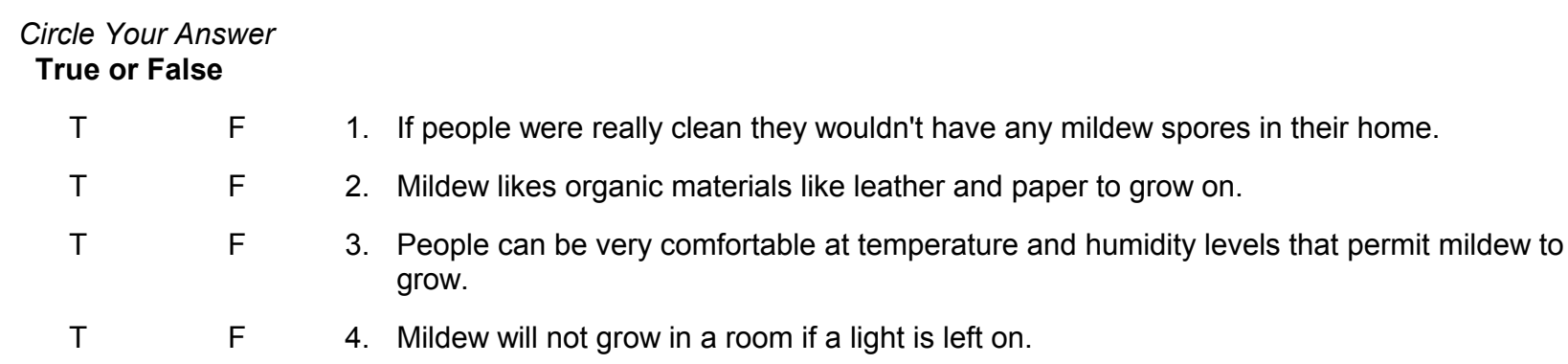

\section{Part II and Part III}

Part II: Provides insight into moisture problems in Florida.

Part III: Helps you deal with moisture in the three mildew hot spots in Florida homes. 